\title{
Pendugaan Musim Tanam Tanaman Pangan Di Kabupaten Parigi Moutong Provinsi Sulawesi Tengah
}

\author{
Sofyan Widiyanto ${ }^{1}$ dan Wenas Ganda Kurnia² \\ ${ }^{1}$ Stasiun Klimatologi Minahasa Utara, Jl Raya Paniki Atas, Kabupaten Minahasa Utara, 95373 \\ ${ }^{2}$ Stasiun Pemantau Atmosfer Global Lore Lindu Bariri, Kompleks Perkantoran Bandara Mutiara Sis Al-jufri,
}

\begin{abstract}
Abstrak. Secara umum, ketersediaan air tanah mempengaruhi jadwal tanam pangan (padi, jagung, cabai, tomat dan kentang). Penyusunan neraca air dimaksudkan untuk meningkatkan produktivitas lahan kering melalui penentuan pola dan jadwal tanam yang sesuai dengan ketersediaan air tanah (KAT). Tujuan dari penelitian ini adalah untuk menduga musim tanam tanaman pangan (padi, jagung, kentang, cabai, tomat) di lahan kering dan basah berdasarkan model neraca air. Data yang digunakan dalam analisis ketersediaan air tanah meliputi curah hujan bulanan dari pos hujan di Kabupaten Parigi Moutong, data suhu udara dari stasiun Meteorologi Mutiara Palu dan Stasiun Meteorologi Lalos Toli-Toli sebagai acuan dalam teori Mock yang digunakan untuk mencari suhu di pos hujan tempat penelitian berdasarkan ketinggian, serta fisik tanah yang terdiri dari nilai kapasitas lahan (KL) dan titik layu permanen (TLP) wilayah Sulawesi Tengah, metode yang digunakan adalah neraca air lahan melalui perhitungan thornhwaite. Hasil penelitian ini menunjukan bahwa Kecamatan Palasa, Ampibabo dan Torue kurang cocok untuk tanaman padi karena ketersediaan air tanah di wilayah tersebut tidak mencukupi untuk tanaman padi, sebaiknya di wilayah tersebut dilakukan penanaman jenis tanaman yang tidak terlalu membutuhkan banyak air, seperti jagung, tomat, cabai dan kentang namun jika irigasi diwilayah tersebut dalam kondisi baik, wilayah tersebut dapat ditanami tanaman padi. Kecamatan Moutong, Siniu, Sausu, Suli, Toribulu, Tinombo Selatan, Dolago dan Baliara cocok untuk tanaman padi dan rata-rata di wilayah tersebut mempunyai 1 (satu) kali musim tanam.
\end{abstract}

(Kata kunci: Neraca Air lahan, Ketersediaan Air Tanah, Tanaman Pangan)

Abstract. In general, the availability of groundwater affect the planting schedule of food crops (rice, corn, chili, tomato, and potato). The preparation of the water balance intended to increase productivity of dry land through the determination of the new pattern and fields sown with corn and schedule for when the that is in accordance with the availability of groundwater (KAT). The purpose of this study is to estimate the growing season of food crops (rice, corn, potatoes, chilies, tomatoes) in dry and wet land based on water balance models. The data used in the analysis of the availability of groundwater of the precipitation rain under this category include of monthly from post of rain in Parigi Moutong Regency, temperature data air came from meteorology station pearls a hammer and meteorology station Lalos Toli-toli as a reference in the theory of Mock is used to looking for the temperature at post the rain the place of research based on the height, and physical land consisting of the total value of the capacity of the acquisition of land $(K L)$ and the point of withers permanent (TLP) the region of central Sulawesi, the methodology that was used of these tests are water balance the acquisition of land for through fees for civil servant employees Thornhwaite. The results of this study show that Palasa sub district, Ampibabo and Torue less suitable for the rice crop because the availability of groundwater in the area were not sufficient to the rice, it is better to plant plants that don't need a lot of water such as corn, tomatoes, chili and potatoes. Moutong, Siniu, Sausu, Suli, Toribulu, South Tinombo, Dolago and Baliara Regency are suitable for the rice crop and the average in the region have once time the planting season.

(Keywords: Land Water Balance, Availability of Ground Water, Food Cropsl)

\section{Pendahuluan \\ Air merupakan faktor produksi yang sangat penting dalam kegiatan usaha pertanian tanaman pangan [1]. Upaya peningkatan produksi tanaman pangan saat ini terganjal oleh berbagai kendala seperti konversi lahan sawah subur yang masih terus berjalan, penurunan kualitas sumberdaya lahan, dan penyimpangan iklim. Penyimpangan iklim menyebabkan}


ketidakjelasan hujan yang turun disuatu wilayah sehingga mempengaruhi ketersediaan air [2]. Ketersediaan air yang sebagian besar berasal dari curah hujan merupakan faktor pembatas yang penting bagi peningkatan produksi suatu tanaman [9]. Neraca air merupakan suatu metode yang dapat digunakan untuk melihat ketersediaan air tanah bagi tanaman pada waktu tertentu, sehingga kekurangan air bagi tanaman dapat diatasi atau dicegah misalnya dengan pemberian air irigasi pada jumlah dan waktu yang tepat. Ketersediaan air merupakan salah satu faktor pembatas yang menetukan jenis dan sebaran tanaman serta periode masa tanam. Setiap jenis tanaman dan sistem usaha tani membutuhkan air yang bervariasi, bergantung sifat genetis dan faktor-faktor lingkungan. Ketersediaan air tanah akan menentukan status air tanaman dan penting dalam proses absorbsi $\mathrm{CO}_{2}[9]$.

Ketersediaan air tanah menjadi hal yang sangat penting untuk dipertimbangkan sebelum melakukan budidaya tanaman. Dapat disimpulkan bahwa penggunaan lahan yang tidak sesuai dapat menurunkan produktivitas dan kualitas produksi tanaman, oleh karena itu pola tanam harus disesuaikan dengan ketersediaan air tanah. Demikian pentingnya fungsi air terhadap tanaman. Karenanya ketersediaan air bagi tanaman pertanian menjadi utama. Pada penelitian sebelumnya dengan tema neraca air lahan di Sulawesi Utara, membuktikan bahwa wilayah-wilayah lumbung padi di Sulawesi utara seperti Kabupaten Bolaang Mongondow dan Minahasa mempunyai nilai ketersedian air tanah dengan kategori cukup hingga sangat cukup, sedangkan untuk wilayah pesisir pantai selatan dan utara mempunyai ketersediaan air tanah yang sangat kurang hingga sedang [2], hal ini membuktikan bahwa pendugaan ketersediaan air tanah untuk kebutuhan pertanian sangatlah penting.

Sebaran hujan yang tidak selalu merata baik menurut ruang dan waktu menyebabkan kondisi ketesediaan air tanah berbeda pula pada setiap ruang dan waktunya. Ketersediaan air tanah merupakan estimasi kondisi air tanah permukaan yang dapat dijelajah oleh akar tanaman, informasi ketersediaan air tanah bertujuan untuk mempertimbangkan kesesuaian bagi pertanian lahan tadah hujan berdasarkan ketersediaan air tanahnya dan mengatur jadwal tanam serta jadwal panen dan mengatur pemberian air irigasi baik dalam jumlahnya maupun waktunya sesuai dengan keperluan [4].

Prakiraan iklim sampai saat ini masih jauh dari sempurna, sehingga dalam pendekatanya taktis dapat dilakukan melalui teknik simulasi dan skenario. Pendekatan neraca air memungkinkan untuk mengevaluasi dinamika air tanah dan penggunaan air oleh tanaman secara kuantitatif [6]. Hal ini dapat dilakukan dengan memantau cekaman air pada tanaman dan mengevaluasi penerapan sistem pertanian irigasi pada kondisi iklim tertentu [7]. Penelitian ini bertujuan untuk menduga musim tanam tanaman pangan (padi, jagung, kentang, cabai, tomat) di lahan kering dan basah berdasarkan model neraca air.

\section{Metodologi \\ Lokasi Penelitian.}

Penelitian ini dilakukan wilayah Kabupaten Parigi Moutong, dimana daerah ini merupakan daerah sentra tanaman pangan Provinsi Sulawesi Tengah. Lokasi penelitian

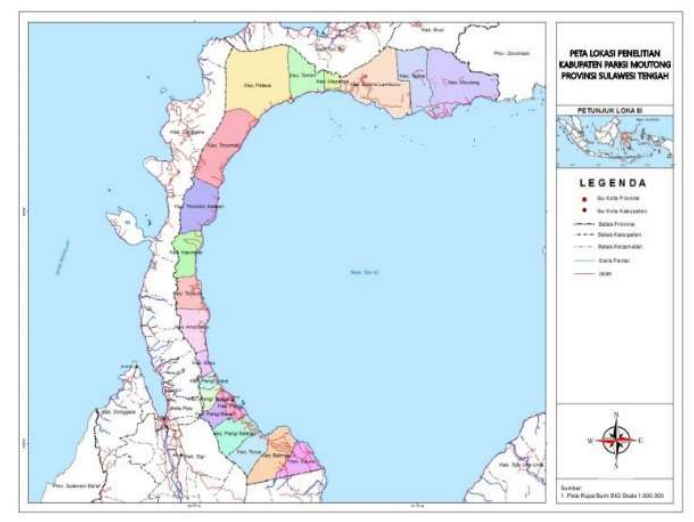

terlihat dalam Gambar 1.

\section{Gambar 1. Lokasi Penelitian.}

Data.

Data yang digunakan dalam penelitian ini adalah data curah hujan bulanan selama tujuh tahun di setiap Kecamatan di Kabupaten Parigi Moutong, data suhu udara tahun 19812010 dari Stasiun Meteorologi Mutiara Palu dan tahun 1997-2016 Stasiun Meteorologi Lalos Tolitoli sebagai titik acuan untuk mencari suhu diwilayah pos hujan penelitian. Data kapasitas lapang dan titik layu permanen di Kabupaten Parigi Moutong [5], data ketinggian pos hujan di lokasi penelitian. Data suhu udara pada setiap pos hujan dihitung berdasarkan interpolasi ketinggian tempat menggunakan teori Mock [8], berikut rumus perhitungannya:

$\Delta t=0,006\left(Z_{1}-Z_{2}\right)$

$\Delta t=$ selisih temperatur antara stasiun

$$
\text { pengukurandan stasiun acuan }\left({ }^{\mathrm{O}} \mathrm{C}\right)
$$

$Z_{1}=$ elevasi stasiun acuan $(\mathrm{m})$

$Z_{2}=$ elevasi stasiun pengukuran (m)

\section{Metode}

Ketersediaan air tanah dihitung menggunakan metode neraca air lahan Thorntwaite dan Mather yang disusun dalam 
skala bulanan [10]. Dalam analisis menggunakan metode ini diperlukan data curah hujan $(\mathrm{CH})$, kandungan air pada tingkat kapasitas lapang $(\mathrm{KL})$ tanah, kandungan air pada tingkat titik layu permanen (TLP), dan suhu udara untuk pendugaan nilai evapotranspirasi potensial (ETP).

\section{a. Perhitungan Evapotranspirasi}

Pendugaan ETP metode Thorntwaite ini hanya menggunakan data temperatur rata-rata bulanan saja. Untuk memperoleh ETP dengan metode ini bisa dilakukan dengan perhitungan menggunakan metode Tornthwaite sebagai berikut [10]:

1) Menghitung indeks panas (i) bulanan:

$$
\mathrm{i}=\left(\frac{t}{5}\right)^{1,514}
$$

2) Menghitung ETP Baku:

$$
\mathrm{ETP}=1,6\left(10 \frac{\mathrm{t}}{\mathrm{I}}\right)^{a}
$$

$\mathrm{t}=$ temperatur rata-rata bulanan $\left({ }^{\circ} \mathrm{C}\right)$

$\mathrm{I}=$ akumulasi indeks panas dalam setahun, diperoleh dengan rumus :

$$
I=\sum_{i=1}^{12}\left(\frac{t}{5}\right)^{1,514}
$$

$$
\begin{aligned}
& a=0,000000675 \mathrm{l}^{3}-0,0000771 \mathrm{l}^{2}+ \\
& 0,01792 \mathrm{I}+0,49239 \\
& a=\text { turunan akumulasi indeks heat }
\end{aligned}
$$

3) Koreksi ETP baku memakai panjang hari (untuk lintang 0,1 hari $=12,1$ jam siang) dan jumlah hari per bulan $=30$ hari, maka:

$E T P=\left(\frac{X}{30}\right)\left(\frac{Y}{12.1}\right) E_{\text {TPaku }}$

$X=$ Jumlah hari dalam satu bulan

$Y=$ Panjang hari dalam jam

4) Koreksi Evapotranspirasi (ETP) dan evapotranpirasi tanaman (ETC)

$$
\begin{aligned}
& \operatorname{ETP}(\mathrm{mm})=\operatorname{ETP}(\mathrm{cm}) \times 10 \\
& \mathrm{ETC}=\mathrm{ETP} \times \mathrm{kc} \\
& \text { Nilai Koefisien tanaman }(\mathrm{kc})
\end{aligned}
$$

b. Perhitungan Neraca Air Lahan

Langkah pengisian tabel neraca air:

1) Kolom Curah hujan $(\mathrm{CH})$

Data $\mathrm{CH}$ rata-rata bulanan atau $\mathrm{CH}$ dengan peluang tertentu.

2) Kolom Evapotranspirasi potensial (ETP). Nilai ETP standar (vegetasi rumput) dengan urutan prioritas sebagai berikut: ETP lisimeter, evaporasi kelas A dikali tetapan, ETP hasil perhitungan/estimasi menurut rumus penman, Thornwaite, Blaney Criddle dan seterusnya.

3) Kolom CH - ETP

Selisih nilai curah hujan dan Evapotranspirasi potensial.

4) Kolom Akumulasi potensial untuk penguapan (APWL).

Hasil-hasil negatif pada langkah 3 diakumulasi bulan demi bulan sebagai nilai Accumulation Potensial of Water Loss (APWL) dan diisikan pada kolom yang bersangkutan.

5) Kolom Ketersediaan air tanah (KAT) pertama tentukan kapasitas lapang $(\mathrm{KL})$. Pengisian kolom KAT dimulai bulan pertama terjadi APWL berdasarkan tabel soil moisture retention atau hitungan rumus.

6) Kolom Perubahan KAT (dKAT) Nilai KAT dari suatu bulan tersebut dikurangi KAT bulan sebelumnya.

7) Kolom Evapotranspirasi Aktual (ETA) Jika $\mathrm{CH}>$ ETP maka ETA = ETP. Pada bulan - bulan terjadi APWL $(\mathrm{CH}<\mathrm{ETP})$ maka $\mathrm{ETA}=\mathrm{CH}+|\mathrm{dKAT}|$.

8) Kolom Defisit (D)

$\mathrm{D}=\mathrm{ETP}-\mathrm{ETA}$

9) Kolom Surplus (S)

Surplus terjadi saat tidak ada $D$, maka $\mathrm{S}=\mathrm{CH}$ - ETP -dKAT.

10) Kolom ATS

Dari hasil KAT tersebut dicari nilai indek/kriteria kebutuhan air bagi tanaman sebagai berikut:

$A T S=\frac{K A T-T L P}{K L-T L P} \times 100 \%$

$$
\begin{array}{ll}
\text { ATS } & : \text { persentase air tanah tersedia } \\
\text { KAT } & : \text { kadar air tanah } \\
\text { TLP } & \text { : titik layu permanen } \\
\text { KL } & \text { : kapasitas lapang }
\end{array}
$$

Hasil dari ATS dibagi menjadi 5 (lima) kelas sesuai presentase kemudian dilakukan pembobotan untuk memudahkan pembacaan pada hasil penelitian, seperti pada tabel berikut [3];

Tabel 1. Persentase Air Tanah Tersedia (ATS).

\begin{tabular}{c|c|c}
\hline $\begin{array}{c}\text { Air Tanah } \\
\text { Tersedia (ATS) }\end{array}$ & Presentase & Bobot \\
\hline Sangat Kurang & $<10 \%$ & 1 \\
Kurang & $10-40 \%$ & 2 \\
Sedang & $40-60 \%$ & 3 \\
Cukup & $60-90 \%$ & 4 \\
Sangat Cukup & $>90 \%$ & 5 \\
\hline
\end{tabular}




\section{Hasil dan Pembahasan}

\section{Analisis Ketersediaan air tanah}

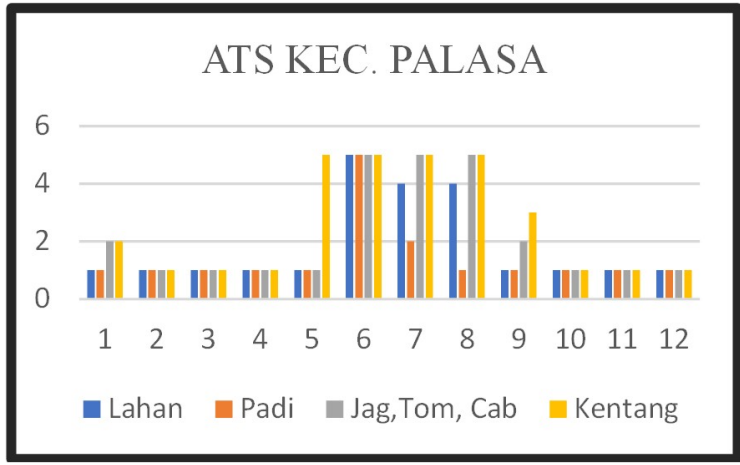

Gambar 2.Pembobotan ketersediaan air tanah Kecamatan Palasa.

Wilayah Kecamatan Palasa dilihat dari Gambar 2. Pembobotan menunjukkan bahwa ketersediaan air yang mencukupi untuk tanaman padi hanya pada bulan Juni, Juli dan agustus, jika dipaksakan melakukan penanaman untuk tanaman padi di kawatirkan tidak mencukupi kebutuhan airnya, sehingga tidak disarankan untuk tanaman padi, namun untuk itu perlu tanaman alternatif lain yang cocok untuk daerah ini yaitu umbi umbian seperti Kentang, Singkong dan Ubi Jalar.

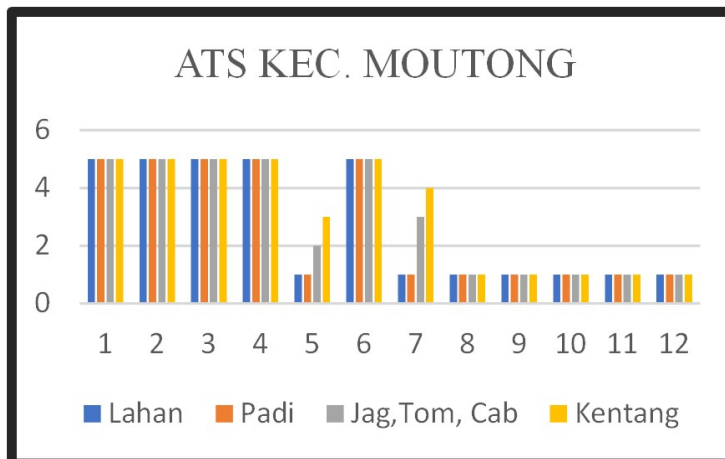

Gambar 3.Pembobotan ketersediaan air tanah Kecamatan Moutong.

Kecamatan Moutong jika dilihat dari Gambar 3. Nilai ketersediaan air sejak JanuariJuni menunjukkan kategori sangat cukup sehingga daerah ini cocok dijadikan lahan pertanian padi. Jika dimasukan nilai koefisien padi nilai ketersedian airnya terjadi di bulan Januari-April. Dalam satu tahun bisa dilakukan penanaman padi sebanyak satu kali, periodenya Januari-April kemudian untuk tanaman jagung, tomat, cabai dan kentang tidak terlalu banyak membutuhkan air sehingga dapat dilakukan penanaman tanaman tersebut sepanjang tahun.

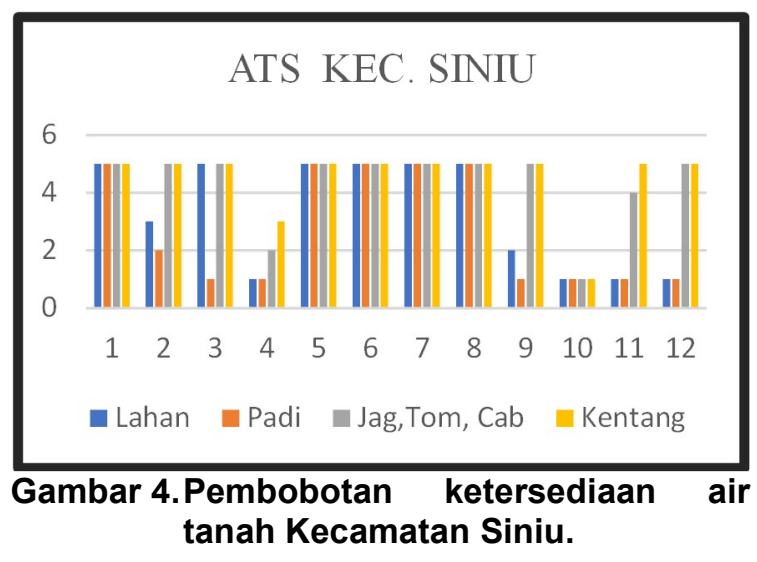

Pada Gambar 4. Ketersediaan air lahan Kecamatan Siniu berada di kategori sangat cukup tersedia dari Januari - Agustus, jika menambahkan nilai koefisien padi menunjukkan ketersediaan air sangat cukup pada bulan Mei Agustus, sehingga daerah ini cocok untuk lahan pertanian padi, dan bisa dilakukan penanaman padi satu kali dalam setahun. Kemudian dapat juga dilakukan penanaman kentang, cabai, jagung dan tomat sepanjang tahun.

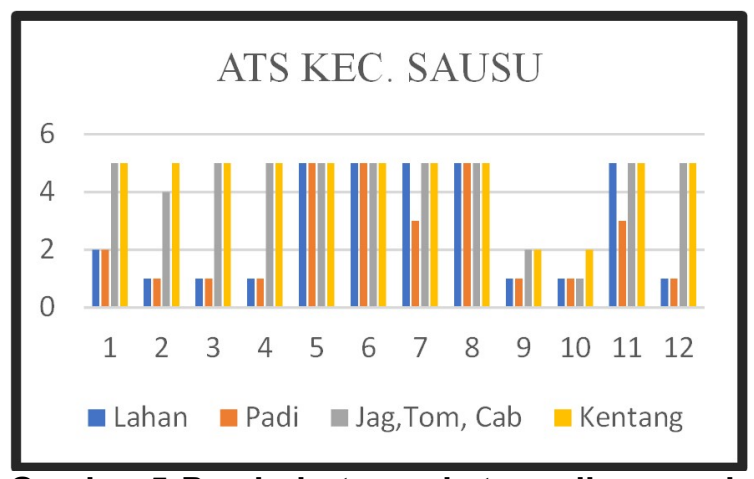

Gambar 5.Pembobotan ketersediaan air tanah Kecamatan Sausu.

Kecamatan Sausu setelah di analisa dari hasil perhitungan menunjukkan untuk ketersedian air sangat cukup pada lahan, sehingga daerah itu cocok dijadikan lahan pertanian tanaman padi, periodenya bulan MeiAgustus, dan jika dimasukan nilai koefisien padi pada perhitungan tersebut menunjukan ada kesesuaian atas kebutuhan air pada lahan tersebut untuk tanaman padi. Dalam satu tahun bisa dilakukan satu kali penanaman padi. 


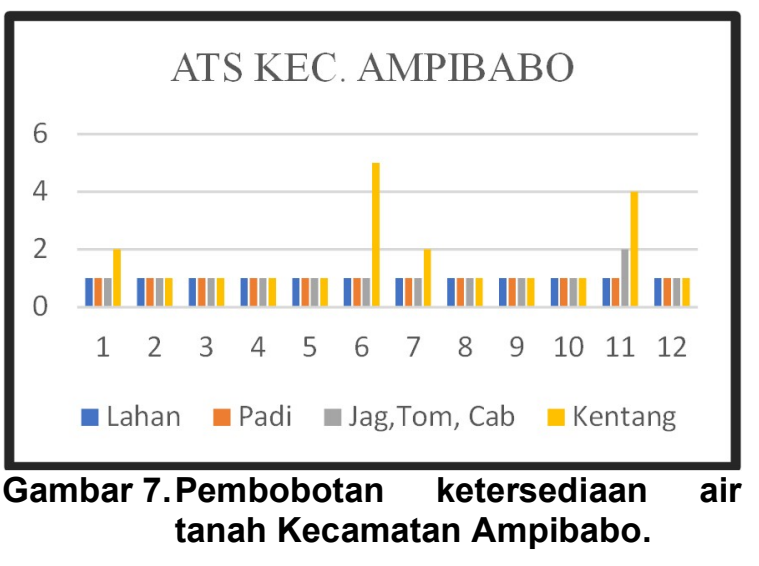

Kecamatan Ampibabo jika dilihat dari Gambar 7. Ketersediaan air tanah pada lahan dan semua tanaman menunjukkan sangat kurang, sehingga tidak disarankan untuk pertanian, namun alternatif lain bisa dilakukan untuk tanaman ubi ubian, jagung, cabai dan tomat, tetapi tetap perlu dilakukan suplai air baik dari irigasi ataupun dari sungai yang di alirkan dengan menggunakan pompa atau kincir air jika daerah ini masuk wilayah Daerah Aliran Sungai (DAS).

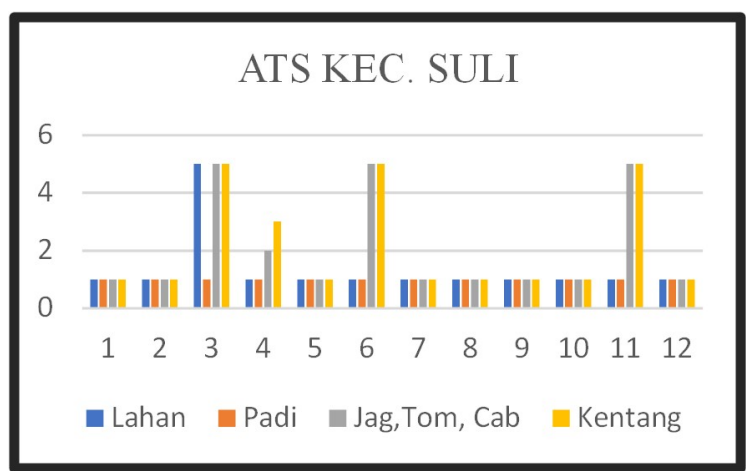

Gambar 8.Pembobotan ketersediaan air
tanah Kecamatan Suli.

Kecamatan Suli dari hasil analisis perhitungan menunjukkan, pada dasarnya untuk ketersediaan air tanah pada lahan sangat kurang, sehingga untuk tanaman padi tidak disarankan namun alternatif lain bisa dilakukan untuk tanaman ubi ubian, Jagung, Cabai dan Tomat, dengan kondisi air lahan yang sangat sedikit tidak memungkinkan untuk ditanami padi, perlu dilakukan suplai air baik dari irigasi ataupun dari sungai yang di alirkan dengan menggunakan pompa atau kincir air jika daerah ini masuk wilayah Daerah Aliran Sungai (DAS). Untuk tanaman Padi tidak disarankan untuk ditanam di daerah ini.

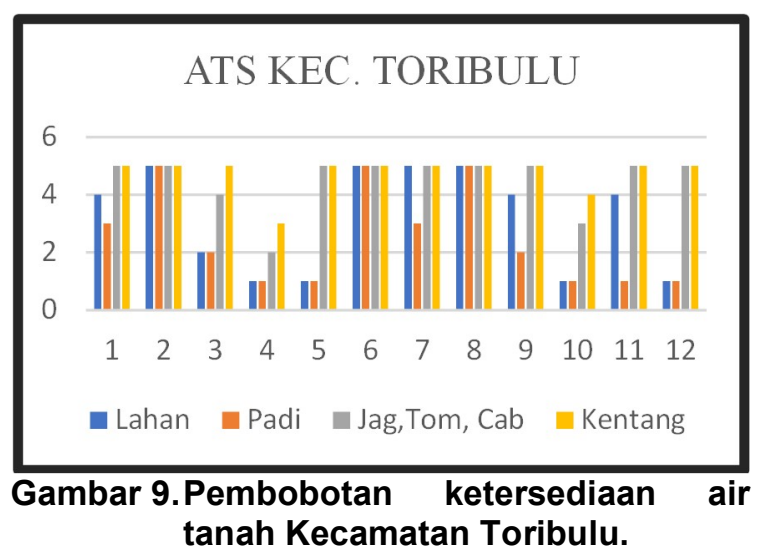

Pada Gambar 9 hasil analisis perhitungan menunjukkan ketersedian air tanah pada lahan sangat cukup sejak bulan Januari November, walaupun ditengah tengah bulan ada beberapa pola grafik yang menunjukan kurang namun masih terpenuhi oleh bulan sebelumnya, setelah menambahkan nilai koefisien tanaman padi menunjukan ada kecocokan jika tanaman tersebut ditanam didaerah ini, Dalam satu tanam padi hanya satu kali dalam setahun. Kemudian untuk tanaman jagung, tomat, cabai dan kentang dapat juga dijadikan tanaman alternatif di daerah ini.

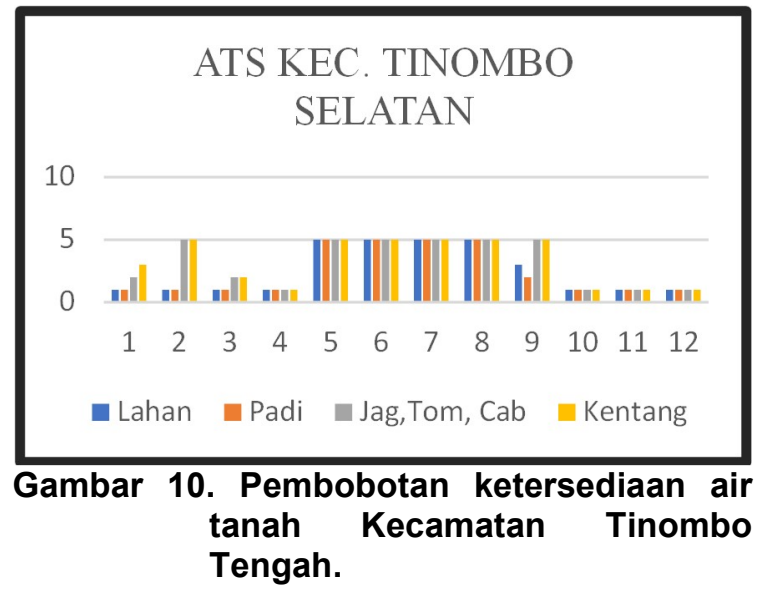

Kecamatan Tinimbo dari hasil analisis data hasil perhitungan menunjukkan terlihat pola ketersediaan air tanah pada lahan menunjukan sangat cukup jika lahan ini digunakan untuk pertanian tanaman padi, terlihat sejak MeiAgustus menunjukkan pola ketersedian air pada lahan sangat cukup, dan jika dilakukan perhitungan dengan memasukan nilai koefisien tanaman padi, maka cocok jika ditanam didaerah ini karena sangatlah cukup ketersedian air tanahnya. Dalam satu periode tanam padi hanya satu kali dalam satu tahun dibulan MeiAgustus. 


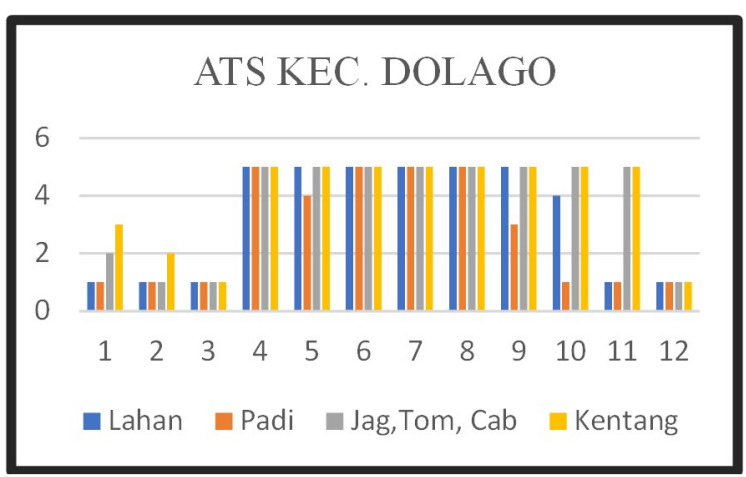

Gambar 11. Pembobotan ketersediaan air tanah Kecamatan Dolago.

Kecamatan Dolago dari hasil perhitungan dan analisa menunjukkan bahwa daerah ini ketersedian air sangat cukup tersuplai pada lahan terlihat dari grafik menujukkan sejak April - September kriterianya sangat cukup ketersediaan air pada lahan tersebut, ini menujukkan daerah ini cocok jika dikembangkan untuk tanaman padi, jika dimasukan koefisien tanam padi ternyata sangat cocok jika dijadikan sentra tanaman padi. Dalam satu tahun bisa dilakukan penanaman padi sebanyak dua kali. Periode April-September.

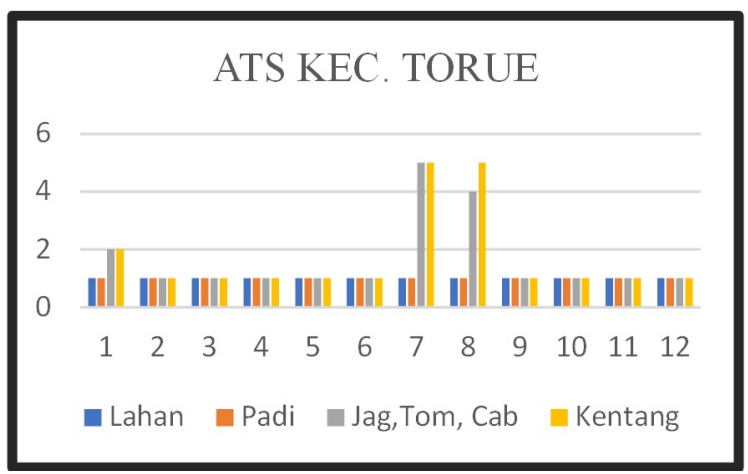

\section{Gambar 12. Pembobotan ketersediaan air tanah Kecamatan Torue.}

Kecamatan Torue dari hasil perhitungan dan analisa data menunjukkan daerah ini untuk ketersedian air tanah sangat kurang, sehingga jika dilakukan penanaman padi sanga tidak cocok karena padi memerlukan banyak air, untuk itu tidak disarakan untuk melakukan penanaman padi di wilayah ini. Namun apabila daerah ini masuk wilayah DAS maka perlu tambahan suplai dari aliran sungai terdekat atau irigasi jika melakukan penanaman padi atau alternatif dengan tanaman yang tidak memerlukan banyak air.

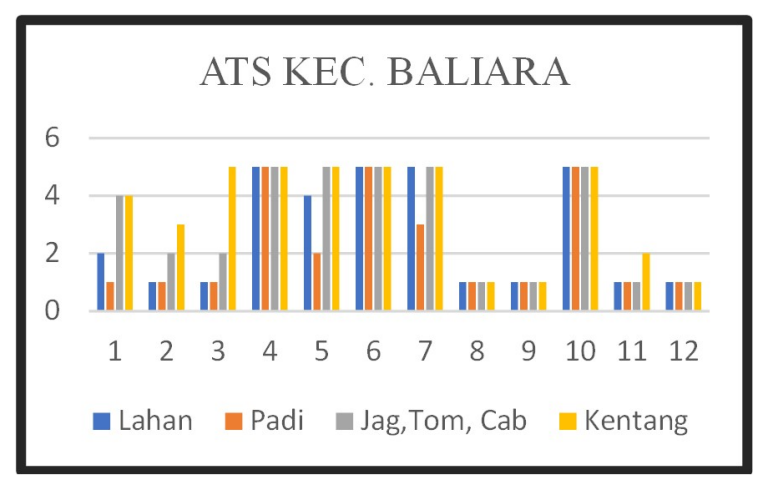

Gambar 13. Pembobotan ketersediaan air tanah Kecamatan Baliara.

Kecamatan Baliara dari hasil perhitungan dan analisa menunjukkan bahwa pada wilayah ini ketersediaan air lahan sangat cukup jika daerah ini digunakan untuk bercocok tanam padi, terlihat dari hasil perhitungan pada bulan April - Juli menunjukan ketersedian air sangatlah cukup jika digunakan untuk tanaman padi. Dan jika memasukkan nilai koefisien tanam padi maka sangat cukup ketersedian airnya. Dalam satu tahun bisa dilakukan penanaman padi sebanyak satu kali tanam. Periode Apri Juli. Kemudian untuk tanaman jagung, tomat, cabai dan kentang dapat dilakukan penanaman sepanjang tahun.

\section{Pemodelan Neraca Air Wilayah Kabupaten Parigi Moutong}

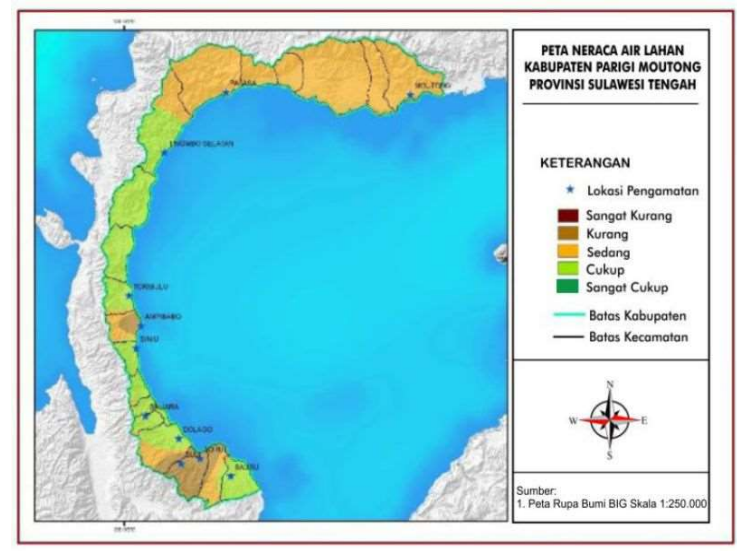

Gambar 14. Peta Neraca Air Lahan Kabupaten Parigi Moutong. 


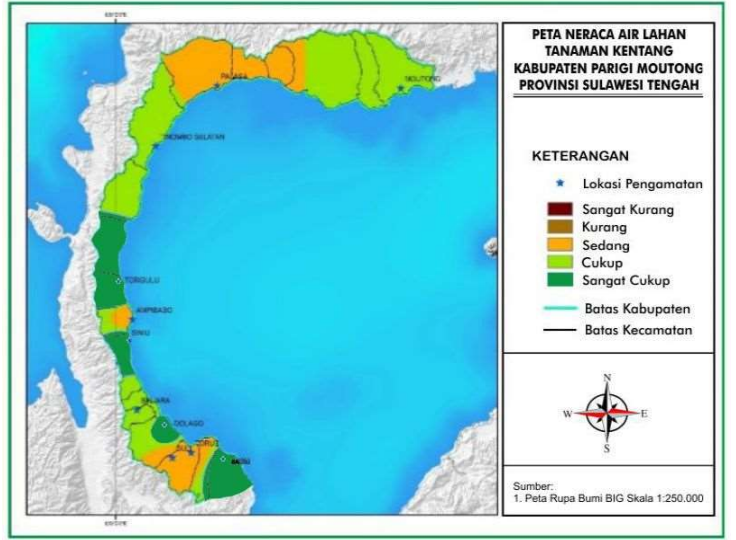

Gambar 15. Peta Neraca Air Lahan Tanaman Moutong. Kentang Kabupaten Parigi

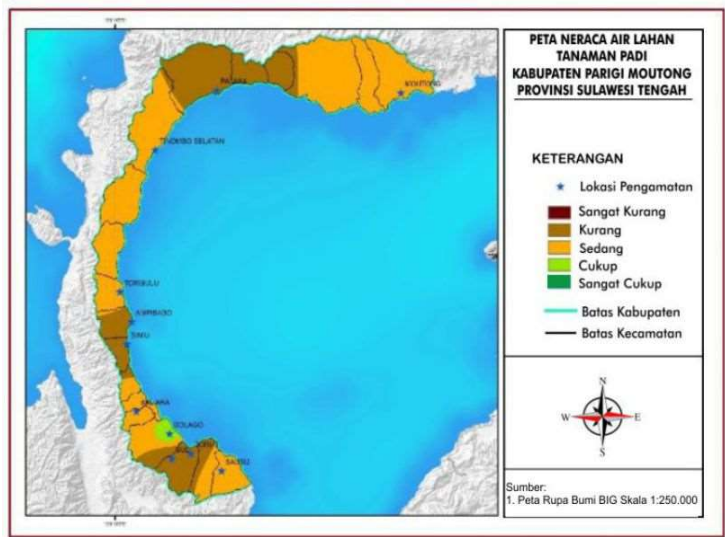

Gambar 16. Peta Neraca Air Lahan Tanaman Padi Kabupaten Parigi Moutong.

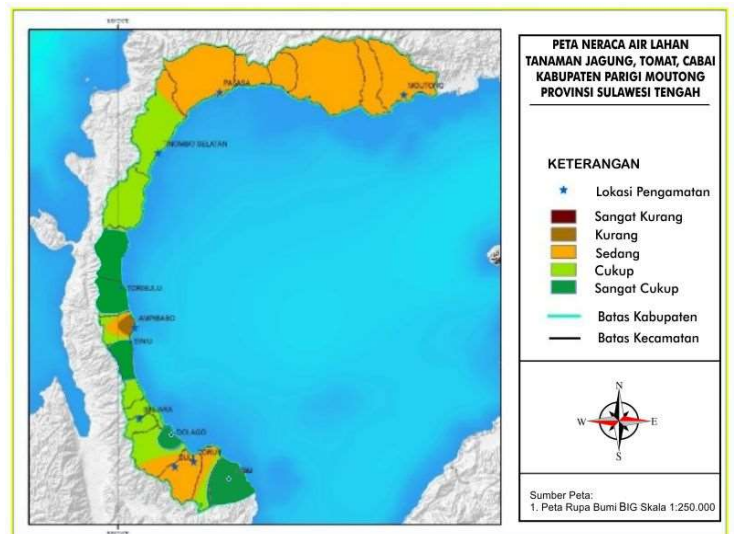

Gambar 17. Peta Neraca Air Lahan Tanaman Jagung, Cabai, Tomat, Kabupaten Parigi Moutong.

Dari hasil pemodelan diatas dapat dilihat ketersediaan air untuk lahan di wilayah Kabupaten Parigi Moutong berada pada kategori sedang hingga cukup. Kemudian untuk ketersediaan air untuk tanaman cabai, tomat, jagung dan kentang berada pada kategori sedang hingga sangat cukup sedangkan untuk tanaman padi mayoritas berada pada kategori sedang.

\section{Kondisi Tanaman Pangan Dan Lahan Sawah Di Kabupaten Parigi Moutong}

Berdasarkan data Badan Pusat Statistik (BPS), Kabupaten Parigi Moutong merupakan lumbung pangan Provinsi Sulawesi Tengah terutama untuk tanaman padi. Seluruh Kecamatan di Kabupaten Parigi Moutong merupakan wilayah sentra padi, hal ini terbukti pada tahun 2016 Parigi Moutong mempunyail lahan padi sawah seluas 52.067 hektar dengan panen mencapai 283.503 ton dan mengalami peningkatan setiap tahunnya [11] bahkan pada tahun 2019 angka panen mencapai 337.999 ton [15]. Namun sebagain besar lahan sawah di Kabupaten Parigi merupakan sawah irigasi, luas sawah irigasi pada tahun 2015 mencapai 30.011 hektare dan sawah non irigasi 2.381 hektare [12].

Kemudian untuk tanaman jagung, pasca bencana gempa tangal 28 September 2018 irigasi di Kabupaten Parigi Moutong menggalami kerusakan sehingga saat ini sebagian lahan sawah irigasi berubah fungsi menjadi lahan jagung, selain faktor tersebut, saat ini Parigi Moutong telah ditetapkan sebagai salah satu kabupaten mandiri benih karena varietas jagung diwilayah tersebut merupakan varietas unggul [14]. Pada tahun 2016 luas lahan jagung di Kabupaten Parigi Moutong adalah 4.508 hektare dengan angka panen mencapai 20.069 ton [11]. Sedangkan seperti tanaman umbi-umbian seperti kentang, ubi jalar dan ubi kayu pada tahun 2016 mempunyai luas lahan mencapai 749 hektare dengan angka panen 12.017 ton [11]. Kemudian untuk tanaman cabai, tomat mempunyai lahan 709 hektare [13] dan dapat ditanam tidak harus musim tanam karena kondisi geografis dan kontur tanah hampir di semua wilayah cukup subur sehingga sangat cocok untuk tanaman pertanian [14].

Jika dilihat dari kondisi tanaman dan lahan yang ada, hasil dari analisis Air Tanah Tersedia (ATS) dan pemodelan neraca air hampir sesuai dengan fakta dilapangan saat ini, hal ini dapat dibuktikan dengan peta neraca air lahan untuk tanaman padi, dari peta tersebut didapatlah hasil bahwa semua Kecamatan di Parigi Moutong dapat ditanami padi sawah dengan satu kali musim tanam dengan bantuan irigasi yang optimal namun ada beberapa Kecamatan seperti Siniu, Sausu, Suli dan Toribulu tanpa bantuan irigasi pun, tanaman padi dapat di tanam di wilayah tersebut. Kemudian untuk jagung, cabai, tomat dan umbi - umbian seperti kentang, dapat ditanam tidak harus pada saat musim tanam karena kondisi ATS dan pemodelan neraca air untuk tanaman tersebut berada dalam kondisi sedang hingga sangat cukup sepanjang tahun. 


\section{Kesimpulan}

Berdasarkan hasil dan pembahasan diatas dapat ditarik beberapa kesimpulan sebagai berikut;

1. Kecamatan Palasa, Ampibabo dan Torue kurang cocok untuk tanaman padi karena ketersediaan air tanah diwilayah tersebut berada pada kondisi ATS kurang hingga sedang, sebaiknya di wilayah tersebut dilakukan penanaman jenis tanaman yang tidak membutuhkan banyak air seperti, jagung, tomat, cabai dan kentang. Namun jika irigasi diwilayah tersebut dalam kondisi baik, wilayah tersebut dapat ditanami tanaman padi.

2. Kecamatan Moutong, Siniu, Sausu, Suli, Toribulu, Tinombo Selatan, Dolago dan Baliara cocok untuk tanaman padi dan ratarata di wilayah tersebut mempunyai 1 (satu) kali musim tanam.

\section{Saran}

Bagi penulis lain yang ingin melanjutkan penelitian ini, atau membuat penelitian yang sama di tempat lain agar mencari data yang lengkap minimal data 10 tahun.

\section{Daftar Pustaka}

[1] S. Helmy, dan B.A. Akbar, "Teknologi Pengendalian Cekaman Air Pada Komoditi Padi dan Kedelai," Jurnal Litbang Pertanian, 2017.

[2] W.G. Kurnia, "Zonasi Daerah Rawan Kekeringan Untuk Tanaman Padi Di Sulawesi Utara." Skripsi, Jurusan Klimatologi: Sekolah Tinggi Meteorologi Klimatologi Geofisika, 2016.

[3] BMKG. Penyusunan Data Indeks Kekeringan Daerah Sentra Produksi Pangan Jawa Tengah 2016.

[4] R.J. Lascano. A General System to Measure and Calculate Daily Crop Water Use.J. Agron 92: 821-832. 2000.

[5] Pawitan, et al. Lokakarya Pemanfaatan Sumberdaya Air. PERHIMPI IPB Bogor. 1996.

[6] R.J. Lascano. Review of Models for Predicting Soil Water Balance. IAHS Publ 199: 443-458. 1991.

[7] D. C. Doraiswamy, and D.R. Thomson. $A$ Crop Moisture Stress Index for Large Areas and Its Aplication in the Prediction of Spring Wheat Phenology. Agric. Meteorological 27: 1-15. 1982.

[8] F.J. Mock. Land Capability Apprassial Indonesia, Water Available Apprassial. 1973.
[9] J.H. Chang. Climate and Agriculture. An Ecology Survey. Chicago: Aldine Publ. Co. 1968.

[10] C.W. Thornthwaite, and J.R. Mather. Instruction and Tables for Computing Potential Evapotranspiration and the Water Balance. Drexel Institute of Technology. Laboratory of Climatology. New Jersey, USA. 1957.

[11] BPS. "Luas lahan, produksi dan panen tanaman pangan"

Internet:

https://parigimoutongkab.bps.go.id/statict able/2016/11/22/84/luas-panen-danproduksi-padi-sawah-jagung-kedelaikacang-tanah-kacang-hijau-ubi-kayu-ubijalar-menurut-kecamatan-di-kabupatenparigi-moutong-hektar-2015.html Akses: Tanggal 13 April 2020.

[12] BPS. "Luas lahan dan Jenis Pengairan di Kabupaten Parigi Moutong." Internet:

https://parigimoutongkab.bps.go.id/statict able/2017/07/18/87/luas-lahan-sawahmenurut-kecamatan-dan-jenis-pengairandi-kabupaten-parigi-moutong-hektar2015.html Akses: Tanggal 13 April 2020.

[13] BPS. "Tanaman dan Jenis Sayuran Di Kabupaten Parigi Moutong." Internet:

https://parigimoutongkab.bps.go.id/statict able/2017/07/18/88/luas-panen-tanamansayuran-menurut-kecamatan-dan-jenissayuran-di-kabupaten-parigi-moutonghektar-2015.html Akses: Tanggal 13 April 2020.

[14] ANTARANEWS. "Tanaman Palawija Parigi Moutong."

Internet: https://sulteng.antaranews.com/berita/42 134/palawija-parigi-moutong-selalutersedia Akses: Tanggal 13 April 2020.

[15] ANTARANEWS. "Produksi Beras Parigi Moutong Tahun 2019." Internet: https://sulteng.antaranews.com/berita/92 711/tahun-2019-surplus-beras-parigimoutong-capai-125000-ton Akses: Tanggal 13 April 2020. 